\title{
Pedagogies afforded by new technologies: The introduction of iPods in one secondary school
}

\author{
Chris Campbell
}

The University of Queensland, School of Education, chris.campbell@uq.edu.au

\begin{abstract}
Mobile technologies such as iPods are making inroads in many aspects of education at St Columba High School in New South Wales. The potential of many of these devices is being explored in a range of educational environments but there has been minimal research to address the effectiveness of this learning tool from the perspective of the student. St Columba's, a co-educational Catholic High School located in the Blue Mountains of Australia, have adopted iPods to replace textbooks for students in Year 8. As a pedagogical approach to learning, the use of iPods can be an advantageous move for secondary schools in light of the Australian government's education "Digital revolution". The aim of this study was to investigate the iPod experience for a small group of Year 8 students and their expectations using iPod Touches for learning. The study aimed to gather data on student expectations of their uses. Data for this study was collected from September to December, 2010, with students completing an online questionnaire using their iPod Touch on the Survey Monkey website. Results are positive and show that students are very keen to use the technology for learning purposes and they have some interesting and realistic expectations on how the iPods can be applied in the classroom.
\end{abstract}

\section{Key Words}

Mobile learning, iPods, Secondary school, middle years, pedagogy

\section{Introduction}

As mobile technologies such as iPods are making inroads in many aspects of education it is important to explore the potential of these devices in a range of educational environments including the secondary school context. However, there has been minimal research to address the effectiveness of this learning tool and its implementation in various settings. The potential of many of these devices is being explored in a range of educational environments but there has been minimal research to address the effectiveness of this learning tool from the perspective of the student.

St Columba's, a co-educational Catholic high school located in the Blue Mountains of Australia, have adopted iPod Touches to replace the use of textbooks for students in Year 8. As a pedagogical approach to learning the use of iPods can be an advantageous move for secondary schools to adopt in response to the need to provide for 21st century learners. The school purchased 190 iPods so that every Year 8 student could have one to use for the school year. Due to delays in obtaining them the iPod touches were purchased and then given to the students just prior to the final school term for the year in 2010. This was in late September as the school year finished in December, 2010. The students were able to use the iPods for learning purposes for the remainder of the year (approximately 10 weeks). The iPod touches were then given to the next Year 8 cohort in February, 2011. These students were able to use them for the entire school year. Such is the success of the 
implementation the school has now gone to a 'bring your own device' policy, with students who are unable being able to do this being able to use the iPod Touches as their device.

Teacher implementation had been a longer and sustained effort at the school with teachers receiving an iPod Touch to use for work purposes the school year prior, which was approximately March, 2009. All teachers then had a lot of time to develop their skills using the iPod Touches and learning about the various apps they might wish to use with the students.

\section{Literature Review}

In recent years the lives and daily routines of many young children are infused by mobile devices or such as mobile phones, iPods and iPads, as they engage with these technologies in a variety of ways (Brown, 2005). With the advent of mobile technologies there is an ever increasing range of technologies available for use within the learning experience of students (Hanewald \& $\mathrm{Ng}, 2011$ ). There is also a reciprocal interaction between students' use of technology and their learning style. Clarke and Dede (2005) noted "adolescents' daily use of new technologies greatly influence their lifestyles toward frequent use of new technologies, which is in turn shaping their learning styles to be inclined with technological devices" (p.1).

It is important for schools to be teaching students using new and emerging technologies so that they may be able to be comfortable and able to use a variety of technology in their everyday lives in the future. Teachers are preparing students to be able to work in jobs that may not exist at that time. Darling Hammond suggests that "the new mission of schools is to prepare students to work at jobs that do not yet exist, creating ideas and solutions for products and problems that have not yet been identified, using technologies that have not yet been invented" (Darling Hammond, 2010).

Today's student populations are often referred to as 'millennial learners' (Oblinger \& Oblinger, 2005) or 'digital-aged learners' or 'digital natives' (Prensky, 2001) as they have been dramatically influenced by information technology (Dale \& Pymm, 2009; Vardy \& Kervin, 2007). These students learning style is characterized as a 'millennial' learning style denoting its exclusive mediabased shifts in learning process (Howe \& Strauss, 2000) that clearly demonstrates how they are different in thinking and processing of information from their precursors (Dede, 2005; Prensky, 2001). Hence the learning environment of these students and how they should be taught need to be changing with the technology they are accustomed to (Brown, 2005), in ways that acknowledge the technology rich environment within which most students operate in their out of school lives (Dede, 2005). Also, teachers need new skills and understandings to better support and engage their 21 st century students in a technology mediated learning environment (Sanford \& Hopper, 2001). It seems based on this that, in recent years, there is a rapid move towards inclusion of mobile technologies like iPods for use in academic setting (Dale \& Pymm, 2009; Hanewald \& Ng, 2011; Read, 2005).

The use of iPods in education is a relatively new concept (Vardy, Kervin, \& Reid, 2007), but one that may have been surpassed with the advent of other mobile devices such as iPads, and windows based mobile devices. Currently, there is a rapid shift toward creatively using technologies, like iPods, for use in the teaching and learning (Read, 2005; Clarke \& Dede, 2007) with mobile technologies having considerable potential to enhance learning and teaching (Shoel \& Banks, 2012). Educators and other related professionals have made considerable efforts towards 
understanding of how the iPod can be used as a learning technology within their learning and teaching practices (Dale \& Pymm, 2009).

\section{Using iPods for educational purposes}

Research shows that iPods play a key role in revolutionizing the classroom for better interactions for both students and teachers (Niemuth, 2010) as it is a flexible tool that can be used for teaching, learning and for self-reflection (Keengwe, Pearson \& Smart, 2009). This technology provides flexible opportunities for learning both inside and outside the classroom (Apple in Education; Barnes \& Goeman, 2007) in a way that is, "innovative, challenging and creative" (Kervin \& Vardy, 2007, p. 63). For example, using iPods, students can record an interview with classmates (Borja, 2005) and they can then further use this for multiple purposes in the classroom. Kervin and Mantei (2008) designed a learning experience using iPod to engage students in collecting and reflecting upon knowledge shared by practitioners in the field.

Seen from another perspective, infusing iPod technology into the academic setting has several benefits in terms of advancing teaching methodologies related to field recordings, classroom recoding, content dissemination, and study support activities (Vardy et al., 2007). Research evidence shows that using new technologies such as iPods in class helps develop student communication skills, which thereby, may assist to overcome obstacles surrounding teaching and learning (Kervin \& Vardy, 2007). This is evident in Kervin and Vardy's (2007) research in which students used iPod Touches to listen to audio books and podcasts as well as create radio shows and their own podcasts. Moreover, an iPod has the potential to provide additional material to enhance in-class instruction (Greer, 2008), promote both independent learning and collaborative interaction of students (Shuler, 2009; Vardy \& Kervin, 2007), and reduce the cost of providing educational content (Greer, 2008). Based on a pilot project to explore the use of iPod touches in the context of a Catholic systemic high school, Heggart (2010) pointed that iPods can be used as part of the teaching strategies used to engage and motivate students and to increase their understanding of basic skills.

The two essential factors that greatly influence teachers' adoption of technology include professional development to assist in teachers' assimilation of technology in instruction and support in the use of technology (Green, 2001). As Shaw (2005) reported, understanding how teachers use technology, their concerns about technology and factors that help produce positive acceptance by teachers are important considerations to successfully implement and expand learning technology in the academic setting (Shaw, 2005). With this connection, Kervin and Vardy (2007) highlighted five strategies for effective use of iPod and podcasting to support the teaching and learning of oral language. The five strategies include: "1. exploring the listening process through podcasting; 2. radio shows to engage students in audio text creation and critical listening; 3 . podcasts to engage students in purposeful, sustained talk; 4. Audio tours to showcase the reality for the students; and 5. Listening and viewing tasks requiring student action using iPods," (Kervin \& Vardy, 2007, pp. 6063).

\section{Using iPods for student engagement and learning}

An iPod is a highly engaging and successful tool that students enjoy using to prepare and deliver learning materials (Borja, 2005). The use of iPod technology offers new possibilities to enhance students learning experience (Dale \& Pymm, 2009), through different strategies such as purposeful 
sustained talking, audio text creation, and critical listening (Kervin \& Vardy, 2007). Furthermore, the use of iPods helps students to maximize their learning engagement. For example, students can record an interview with classmates that show their generative potential to produce learning materials and create wider accessibility (Borja, 2005). Examining the results of a recent research study, Richardson (2006) suggests some best practices of iPod use in education through a "summary podcast" in the K-12 environment.

An iPod is beneficial both for those students who are academically talented and for those who are academically reluctant (Vardy et al., 2007). Research shows that iPod stimulates interest to academically engage those students who are dis-engaged and dis-interested, at the same time, providing better advanced learning opportunities for those students who are academically talented to use iPods to discover successful learning experiences (Heggart, 2010). In older research, Saunders and Moore (2003) identified iPods as a suitable device for the storage and transfer of files, particularly in such environment where learning happens in distance learning mode. For instance, the iPod can be used to store video clips for instructional purposes, without the inconvenience of carrying DVD's or CD's and moving bulky audio-visual equipment. This is supported by Shohel and Banks (2012) who report the use of video is an enhancement to learning as they can be preloaded onto the iPods or downloaded as needed.

Seen from another perspective, Switzer and Csapo (2005) argue that mobile technologies such as iPods provide greater opportunities for students' team work and information sharing among them. This could help them to demonstrate their own understandings and to learn from the understandings of others (Kervin \& Vardy, 2007). Also the iPod capability of capturing audio data is seen as a nonnative function of the iPod, in a sense that the iPod serves as a convenient way to improving language learning (Slykhuis, 2006). In a pilot project, Lennex (2008) explored the use of video iPods in middle schools in two social studies classrooms and found out that providing opportunity for students to review materials whenever they want to without jeopardizing the works of others in the class has a significant effect on students ability to individualise the learning experience to best suit their needs and take more responsibility to engage with the material.

When integrated into instruction appropriately, iPods have significant positive effects on student achievement across different disciplines such as: reading fluency and comprehension, literacy, mathematics, science, and social studies (Heggart, 2010; Vardy \& Kervin, 2007; Vardy et al., 2007; Dale \& Pymm, 2009). Also, integrating iPods into instruction can help students learn 21st century skills in addition to core academic subjects (Vardy et al., 2007). For this to happen, it is generally recommended that instruction should be hands-on, flexible and contextual (Vardy \& Kervin, 2007).

\section{Teachers changing pedagogy}

To incorporate mobile devices, including iPods into their teaching then teachers need to change their pedagogy in order to use these devices. Although this does happen in schools it is important that teachers transform their traditional pedagogies in order to benefit their students (Keengwe, Pearson \& Smart, 2009). Unfortunately making the technology available does not mean that students and teachers automatically know how to use them (Crompton, 2011) and thus it is necessary to teach both students and importantly teachers how to use the devices. 
In a study of pre-service teachers using iPods, Kervin and Mantei (2009), report it is important to have good access to mobile technologies and it is necessary to allow exposure so that the devices potential can be used and to allow teachers to gain confidence when using the tool. This suggests that exposure to mobile technologies is a key to changing pedagogies that relate to technologies in a school.

It has been suggested that for "seamless integration of mobile technologies in instruction [it] requires schools to ensure that technology implementation and vision supports the overall educational goals of their students" (Keengwe, Pearson \& Smart, 2009, p.343). This is important so that there is a systematic approach with schools determining the types of technology that will support their goals. All parties in the school from parents, to teachers, to students should then be informed of these goals and it should be reinforced that the technology is being used to support and improve teaching and learning (Keengwe, Pearson \& Smart, 2009). In this way, the pedagogies being used in the school can be changed and mobile technologies more seamlessly integrated into teaching.

\section{Methodology}

This study was conducted at the instigation of the school with the researcher visiting the school on numerous occasions to collect the data. Thus, the ethics approval process was begun and was granted by the university as well as by Catholic Education. Signed permission was obtained by the Assistant Principal at the school and the students and their parents/guardians prior to any data being collected.

The aim of this study was to investigate the iPod experience for a group of Year 8 students at St Columba's Catholic High School in New South Wales, Australia. The following research questions were developed as a response to the initial meetings with the Deputy Principal of the school. These are:

1. What are the student expectations in using iPod Touches in their school?

2. What are the student experiences in using iPod Touches in their school?

3. In what ways does the use of iPod Touches in class change student interaction with teachers?

Data was collected through the use of online questionnaires and through focus group interviews. The Assistant Principal of the school was generally available and in the room when the students were interviewed as the entire project and iPod Touch implementation was through the initiative of this Assistant Principal who had worked hard for several years to enable the school to purchase them for staff and student use. The focus group interviews were conducted to enable more in-depth data to be collected from the students and to gain greater insight into their survey answers. In the focus group interviews students were asked questions such as in what ways have they been using their iPod Touch and how they think they might be able to use them in the future.

Data collection occurred in 2010 when the students were given the iPod Touches. After the ethics consent forms for this study had been returned the students were given their iPod Touch and directed to the online initial questionnaire which they completed. They completed this in September, 2010, and a few weeks later in October, 2010, the students completed the first mini questionnaire, which was after a two week school holiday. They then completed a second mini 
questionnaire in November 2010. To add to the questionnaire data the focus group interviews occurred in October and in December of that same year, which was in the week after the mini questionnaires.

The online questionnaire was the primary data collection tool concerning the student's expectations of using an iPod for learning with 167 students completing the questionnaire. The questionnaire required the students to examine their student experience of using iPods when incorporated as a learning tool. Documenting the student experience was important because it raised an awareness of the specific needs, attitudes and requirements of the student perspective of using iPods for learning, and indicated if their experiences with this technology were positive and if they remain constant throughout the school year. Students were also asked if using an iPod in class motivates them to learn and in what ways does it do this.

Other data has also been collected as part of this project. This included two mini questionnaires while the students were using the iPods with the students being asked about how they were using their iPod in class. These questionnaires were designed to be completed fairly quickly by the students and were administered one month apart with each questionnaire asking the students the same questions. Students were specifically asked if they had used their iPod Touch in a new way in the past week and if so in what new ways had they used them. They were asked if they had any problems using the device and how they felt their learning had improved in the previous week by using the iPod Touch in class time.

Focus group interviews were also conducted in October and December which allowed for more indepth data to be gathered. These interviews were transcribed and coded for emerging themes. The interview questions for the focus group interviews were designed to give students the opportunity to share their experiences in detail and to potentially expand on the questions asked in the questionnaire and mini-questionnaires. Specifically questions included the ways they were used and how they "think they should be used in class for educational purposes". Students were also asked "how did you actually use them in class" and "what sort of things did you use them for that supported your learning". Finally students were asked to describe any problems they had with the devices and how these were solved.

\section{Results and Discussion}

Results are positive and show that students are very keen to use the technology for learning purposes and they have some interesting and realistic expectations on how the iPods can be used in the classroom. Results were particularly positive in the subject areas where teachers have changed their pedagogy to integrate the iPods into their class lessons.

The results have been broken into several key areas. These include the background of student internet and computer access as well as student expectations and the use of the iPods and student interaction with teachers. Student expectations is a primary focus of this paper which includes the key themes which are using the iPod touch for learning, the advantages and disadvantages of having an iPod touch and motivation to learn with an iPod touch. The results section will go through these areas and themes in a systematic fashion.

\section{Background}


All students except for one had the use of a computer at home with $81.3 \%(n=130)$ having fast Internet access and $18.1 \%(\mathrm{n}=29)$ had slow access to the Internet. The student without a computer at home had no Internet access. Over $82 \%(n=131)$ of students have a mobile phone while more than $60 \%(\mathrm{n}=96)$ use a PlayStation.

Two thirds of students were given unrestricted access to a computer at home ( $\mathrm{n}=108)$ as well as the Internet on that computer $(n=107)$ with 6 students not answering either question. Students were asked how often they used the computer at home in various ways such as playing games, listening to music and researching information.

\section{Student Expectations}

Students were asked to describe how they will use the iPod Touch for learning. As can be seen in Table 1, students answered in a variety of ways including $40 \%(\mathrm{n}=68)$ saying they will have greater use of the Internet, while 34\% ( $\mathrm{n}=57$ ) plan on using the iPod Touch apps. Another theme in the results is the term research with $26 \%(\mathrm{n}=45)$ of students commenting using this research while in class at school. One student "I will use it to find things on the Internet. I would always have it with me," while another stated "I will use the iPod to gain information from the Internet quickly". One student recorded the comment "I would use the iPod touch by using the convenience of internet use, apps and other aspects to extend and make my learning easier and possibly have more enjoyment over textbooks and other techniques". While another stated:

The iPod touch will be used for learning by using all the apps to work confidently. We will have all our learning equipment on there, and there we can't forget anything for our classes.

Table 1: Student expectations of using an iPod at school

\begin{tabular}{|c|c|c|c|c|c|c|}
\hline Statement & $\begin{array}{l}\text { Response } \\
\text { Count }\end{array}$ & $\begin{array}{l}\text { Strongly } \\
\text { Disagree }\end{array}$ & Disagree & $\begin{array}{l}\text { Don't } \\
\text { know }\end{array}$ & Agree & $\begin{array}{l}\text { Strongly } \\
\text { Agree }\end{array}$ \\
\hline $\begin{array}{l}\text { I believe an iPod will improve my } \\
\text { academic ability at school }\end{array}$ & 167 & 0 & $\begin{array}{l}1.2 \% \\
(\mathrm{n}=2)\end{array}$ & $\begin{array}{l}14.4 \% \\
(\mathrm{n}=24)\end{array}$ & $\begin{array}{l}64.7 \% \\
(\mathrm{n}=108)\end{array}$ & $\begin{array}{l}19.8 \% \\
(\mathrm{n}=33)\end{array}$ \\
\hline $\begin{array}{l}\text { I believe using an iPod will increase my } \\
\text { motivation to learn }\end{array}$ & 167 & 0 & $\begin{array}{l}1.2 \% \\
(\mathrm{n}=2)\end{array}$ & $\begin{array}{l}9.0 \% \\
(n=15)\end{array}$ & $\begin{array}{l}55.1 \% \\
(\mathrm{n}=92)\end{array}$ & $\begin{array}{l}34.7 \% \\
(\mathrm{n}=58)\end{array}$ \\
\hline $\begin{array}{l}\text { It is important that my confidence to } \\
\text { learn is increased as a result of using an } \\
\text { iPod at school }\end{array}$ & 167 & 0 & $\begin{array}{l}1.8 \% \\
(\mathrm{n}=3)\end{array}$ & $\begin{array}{l}21.6 \% \\
(n=36)\end{array}$ & $\begin{array}{l}52.7 \% \\
(\mathrm{n}=88)\end{array}$ & $\begin{array}{l}24 \% \\
(\mathrm{n}=40)\end{array}$ \\
\hline I am confident using an iPod & 167 & $\begin{array}{l}0.6 \% \\
(\mathrm{n}=1)\end{array}$ & $\begin{array}{l}1.8 \% \\
(\mathrm{n}=3)\end{array}$ & $\begin{array}{l}7.2 \% \\
(\mathrm{n}=12)\end{array}$ & $\begin{array}{l}34.1 \% \\
(\mathrm{n}=57)\end{array}$ & $\begin{array}{l}56.3 \% \\
(\mathrm{n}=94)\end{array}$ \\
\hline $\begin{array}{l}\text { Using an iPod motivates me to learn or } \\
\text { put forth my greatest effort at school }\end{array}$ & 167 & 0 & $\begin{array}{l}0.6 \% \\
(\mathrm{n}=1)\end{array}$ & $\begin{array}{l}13.8 \% \\
(\mathrm{n}=23)\end{array}$ & $\begin{array}{l}54.5 \% \\
(\mathrm{n}=91)\end{array}$ & $\begin{array}{l}31.1 \% \\
(\mathrm{n}=52)\end{array}$ \\
\hline
\end{tabular}

Results from the initial questionnaire suggest students felt there were many advantages to having an iPod Touch for use at school. Students felt that the iPod Touch would help with learning and that it would replace their text books. This may have been because the students were told this would happen in the future and thus this expectation had been previously set amongst the students. Student comments suggest they are positive towards using an iPod Touch while at school. One student commented "the advantages of the iPods will be that [it] can download applications to help our 
learning", while another student commented "one of the advantages are making learning more fun and motivating the students to try harder". Another reported "it will make learning more enjoyable and I think easier to understand".

Students appeared to be aware of some of the potential disadvantages to using an iPod while at school. Reasons students indicated were that they might break or be damaged through dropping the iPod, they might be a distraction in class and that some students might use them in class to play games. Other students commented on battery life and losing the iPod or forgetting to bring it to school. One student commented "the disadvantages of having an iPod touch is always having the possibility of it getting broken, lose, or stolen and having to pay if this happens" while another recorded:

The disadvantages are that some kids might not use them with care and they might do the wrong stuff on the iPods and get distracted by the apps they have put on themselves."

Another student commented on various disadvantages "people may play with them during class, break the iPod or use it for the wrong reasons. They may also forget to bring them to school."

\section{Uses of the iPods}

Students report using the iPods more in some subjects than in others with students consistently reporting the iPod Touch's being used in science, music, religion, English, and languages which in this case was Japanese, and mathematics.

During the mini questionnaires conducted during the study the students were asked in what ways they have used their iPod during the week. Figure 1 shows that students used their devices for a variety of tasks during Weeks 1 and 6 of the school term. There were 98 students who completed the questionnaire in Week 1 of Term 4 and 118 students who completed the questionnaire in Week 6 of Term 4. 


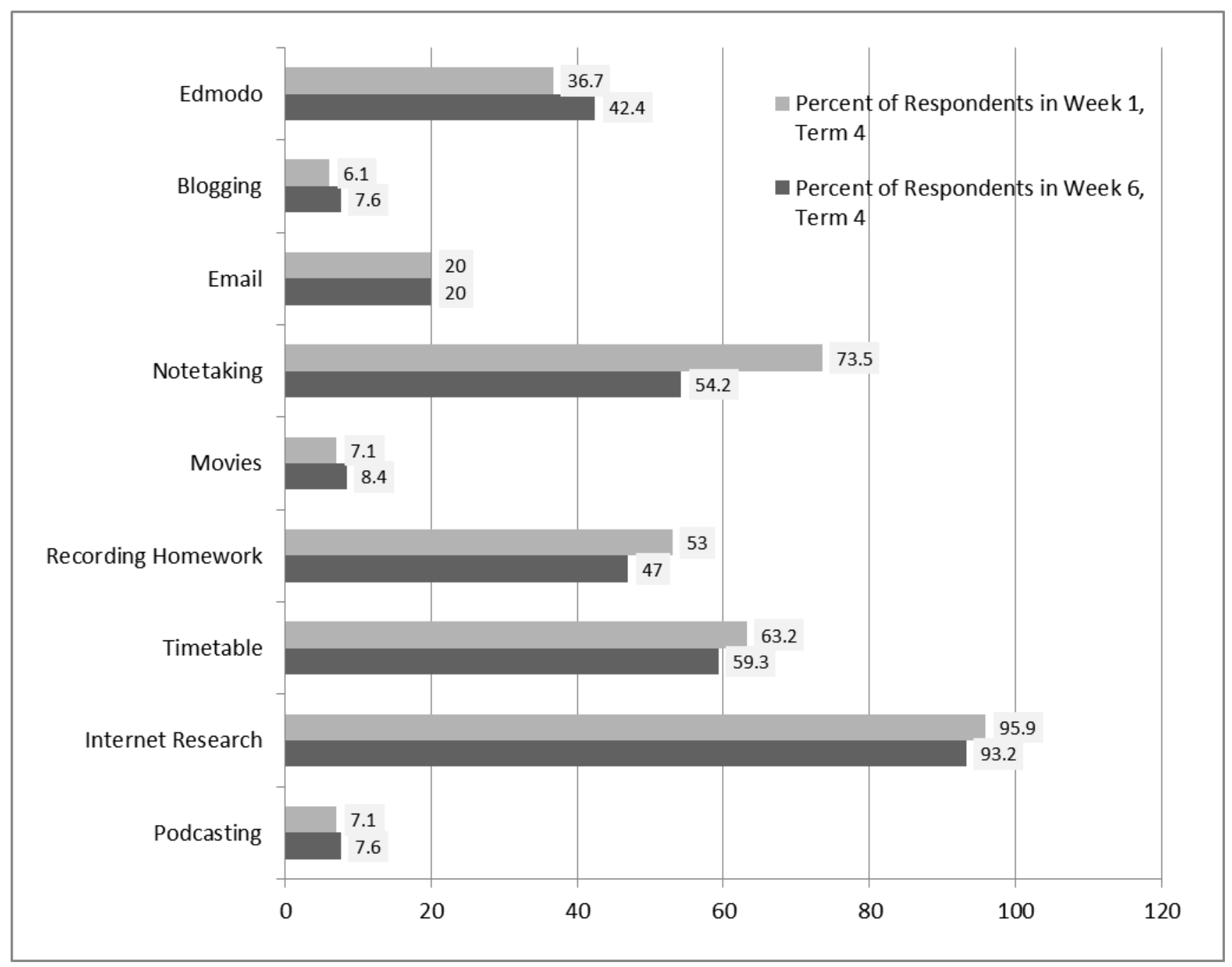

Figure 1: Ways students have used the iPods at school in Weeks 1 and 6, Term 4

By viewing Figure 1 it can be seen that the types of activities that the students completed in the previous week to completing the questionnaire were similar. As the school term was 10 weeks this shows an even spread of activities as the questionnaires were conducted half a school term apart as the mini questionnaires were conducted in Weeks 1 and 6 of Term 4. Results are fairly consistent with the biggest change in the use of Edmodo which saw an increase from $36.7 \%(n=36)$ students to $42.4 \%(\mathrm{n}=50)$ students using it in class. The biggest decrease was in Note Taking which was a decrease in students using their iPod Touch for this purpose from $73.5 \%(n=72)$ to $54.2 \%(n=64)$. Only one feature went down and that was the use of the note taking apps.

In Week 6, there were $59.3 \%(n=70)$ students who checked Timetabling as a way they used their iPod Touch, as can be seen in Figure 1. This is similar to the Week 1 results of $63.2 \%(n=62)$.

Timetabling refers to the fact that their school timetable is on the iPod. In a focus group interview one student commented:

And it's also good for just organising like timetables and notes. Just when I think of something, and I can just write it down. Because that's good for timetables too, 
because you don't have to go through your bag to get your timetable out and everything.

The focus group interviews support the table results with some students stating they use Evernote (an application) for note taking and others using eNotes for keeping a daily journal. These are free apps that were suggested by the school and students were encouraged to load onto their devices. Some teachers encouraged the use of note taking in their classes and students reported that they used it in class with those teachers, but not with others.

Edmodo is a closed social networking/learning management system environment where the teacher can add the students (or the entire school) and they can all use the system in a safe environment and in class groups. It has a large variety of features that teachers can access including connecting the students to various resources, using assessment tools and it allows teachers and students to connect and collaborate in a closed and safe environment. Students report using Edmodo for their science classes, and sometimes for the subject called PDHPE (Personal Development, Health, and Physical Education). In class the students were able to look at video clips that other students have found with Edmodo providing a way of them to share the videos in a safe environment. This is distinct to the students who watched movies on their iPod Touches of which only a small number did so.

Students also reported using specific apps for the topics they are studying such as the Sleep Cycle app in science. They also use map games, flash cards, Instapaper to capture websites to then look at offline as well as the Internet for researching topics. One student commented on using little flash cards and instead of hand writing them they are using a particular app to assist with this. The student commented:

In Japanese, we're writing little flash cards, so we can, again, go back and look at them before tests. In English, we also use them for research for our assignments and stuff.

Once again, some teachers encouraged the use of particular apps in class and suggested the students download them while others did not encourage them. One example is the Japanese teacher who suggested apps for the students to help them with the language. This actually led to students looking in iTunes for other apps and then suggesting them to the teacher if they thought they were good. The students found this very motivating and would often do this while on their lunch breaks (as evidenced by the researcher when visiting the school).

\section{Student Interaction with Teachers}

While many students feel that their interaction has not changed through the introduction of the iPods other students feel that it has. One student reported "I have interacted with teachers a bit more but I find it easier now when they are busy I can use it [the iPod Touch] to help with my problems" suggesting this student finds it very useful to seek assistance from the programs on the iPod. Other students feel it has changed their interaction in some classes. One student used science as an example which is interesting as another student reported helping the teacher in science with the use of the iPod touch. This student reported:

but I have showed my teacher's how to use the iPods in new ways link in science we had to draw a diagram but $u$ [sic] can't with notes so I download touch paint (a fully free app that allows to draw what $u[s i c]$ need). 
Finally, in one of the student focus groups they were asked to give the iPods a rating out of 10 with regards to how the students enjoy using them. One student responded " 8 or 9 " and when asked what would make it a 10 the response was to use it a lot more in class. When questioned further and asked to discount the game machine factor the students in the focus group rated it between 5 and 7 . To increase this number and make it a 10 the students felt they would like "to use it more often". By using "it more often" the students are referring to using it in each class, or in more classes as this was an arbitrary term identified by them. This suggests the teachers as a whole need to continue to adapt and change their pedagogy to incorporate the technology more often into their lessons.

\section{Conclusions}

As teachers become more knowledgeable and comfortable using technologies (Keengwe, Pearson \& Smart, 2009) in their classroom then their pedagogy will change and they will be able to integrate technologies more readily into their classroom with student learning to benefit from this. In this case study this is becoming evident in some of the classes that the students are undertaking.

In 2012 the school has gone to a 'bring your own device' policy with students being able to bring in devices such as iPads, iPod Touches, iPhones as well as android devices. This will allow students flexibility in the device they take to school, although students without a device will be given a school iPod Touch for the year. One negative is that teachers may have increased technical problems teaching with a variety of devices, while other teachers may be able to easily overcome any potential adversities due to their greater skill level of using a variety of devices.

Although providing the iPod Touches does not mean that teachers will be able to teach with them (Crompton, 2011) this school went to great lengths to provide teacher professional development and support to enable the teachers to feel confident in using the devices. In time it is hoped that more teachers will be able to implement the use of iPod touches as a tool for learning.

This school is attempting to change teachers' pedagogy to accommodate the needs of today's millennial learners (Oblinger \& Oblinger, 2005). Although research is relatively new in the use of iPods in education it has been shown that mobile technologies have considerable potential in their ability to enhance student learning (Shoel \& Banks, 2012). This study concludes that when the iPods are used in the classroom successfully that students feel they help improve their learning.

\section{Acknowledgements}

The author would like to express gratitude St Columba's High School in Springwood, New South Wales, Australia, for allowing her to collect the data required for this paper. In particular the author would like to thank the Assistant Principal, Mr Phillip Stewart for his generosity and sharing of information.

\section{References}

Barnes, P. \& Goeman, B. (2007). The use of iPod technology in counselor education: Enhanced assessment through new teaching methodology. In R. Carlsen et al. (Eds.), Proceedings of Society for Information Technology \& Teacher Education International Conference 2007 (pp. 22-27). Chesapeake, VA: AACE. Retrieved from http://www.editlib.org/p/24493 
Borja, R. (2005). Podcasting craze comes to K-12 schools. Education Week, 25(14), 8-8.

Brown, M. ( 2005). Learning spaces. In D. G. Oblinger, and J. L. Oblinger. (Eds.), Educating the Net Generation. (pp. 12.1 - 12.22). Retrieved from: http://net.educause.edu/ir/library/pdf/pub7101.pdf

Clarke, J., \& Dede, C. (2005). Making learning meaningful: An exploratory study of using multi-user environments (muves) in middle school science. Paper presented at the American Educational Research Association Conference, Montreal.

http://muve.gse.harvard.edu/rivercityproject/documents/aera_2005_clarke_dede.pdf

Crompton, H. (2011). Mathematics in the age of technology: There is a place for technology in the mathematics classroom. Journal of the Research Center for Educational Technology (RCET), 7(1), 54-66.

Dale, C., \& Pymm, J. (2009). Podagogy: The iPod as a learning technology. Active Learning in Higher Education, 10(1), 84-96.

Darling Hammond, L. (2010). The flat world and education: How America's commitment to equity will determine our future. New York: Teachers College Press.

Greer, C. (2008). iPod: An Educational Tool for the Modern P-12 Classroom. In K. McFerrin et al. (Eds.), Proceedings of Society for Information Technology \& Teacher Education International Conference 2008. (pp. 922-924). Chesapeake, VA: AACE. Retrieved from http://www.editlib.org/p/27290

Hanewald, R. and Ng, W. (2010). The digital revolution: Digital citizenship and multi-literacy of mobile technology users. In Ng, W. (Eds.), Mobile technologies and handheld devices for ubiquitous learning: Research and pedagogy, (pp. 1-14). USA: Information Science Reference.

Heggart,K. (2010). The iPod trial program at McCarthy Catholic College, Emu Plains. Available: http://www.mirandanet.ac.uk/ejournal/uploads/857/iPod_Touch_Research_Paper.pdf

Howe, N., \& Strauss, W. (2000). Millennials rising: The next great generation. New York: Vintage. Retrieved from: http://www.johnreilly.info/miri.htm

Keengwe, J., Pearson, D. \& Smart, K. (2009). Technology integration: Mobile devices (iPods), constructivist pedagogy, and student learning. AACE Journal, 17(4), 333-346. Chesapeake, VA: AACE.

Retrieved from http://www.editlib.org/p/29411.

Kervin, L. \& Mantei, J. (2008). Taking iPods into the field to capture and share teacher wisdom stories. In Hello! Where are you in the landscape of educational technology? Proceedings ascilite Melbourne 2008. Retrieved from: http://www.ascilite.org.au/conferences/melbourne08/procs/kervin.pdf

Kervin, L., \& Mantei, J. (2009). Collaborative gathering, evaluating and communicating 'wisdom' using iPods. In J. Herrington, A. Herrington, J. Mantei, I. Olney, \& B. Ferry (Eds.), New technologies, new pedagogies: Mobile learning in higher education. (pp. 99-109). Wollongong: University of Wollongong. Retrieved from http://ro.uow.edu.au/

Kervin, L. \& Vardy, J. (2007). Look who's talking: Incorporating iPods in the classroom. Screen Education. (48), 58-64. 
Lennex, L. (2008). Digital natives and the use of video iPods: a Lewis and Clark expedition. In C. Crawford et. al. (Eds.), Proceedings of Society for Information Technology and Teacher Education International Conference 2008. (pp. 4913-4915). Chesapeake, VA: AACE.

Niemuth, T. (2010). NEW TOOLS for student engagement. Leadership, 39(3). 24-27.

Prensky, M. (2001). Digital Natives, Digital Immigrants. Available: http://www.marcprensky.com/writing/prensky\%20$\% 20$ digital\%20natives, \%20digital\%20immigrants\%20-\%20part1.pdf

Oblinger, D.G \& Oblinger, J.L. ( 2005). Introduction. In D. G. Oblinger, and J. L. Oblinger. (Eds.), Educating the Net Generation. (pp. 1.1 - 1.5). Retrieved from: http://net.educause.edu/ir/library/pdf/pub7101.pdf

Read, B. (2005). Seriously, iPods are educational. Chronicle of Higher Education, 51(28). A30-A32.

Saunders, J., \& Moore, E. (2003, September 21-24). ipod, upod, wepod. Doubling your client support and strengthening team ties with virtually no extra resources. Paper presented at the SIGUCCS, San Antonio, USA.

Shoel M.M.C. \& Banks, F. (2012). School-based teachers' professional development through technologyenhanced learning in Bangladesh, Teacher Development: An International Journal of Teachers' Professional Development, 16(1). 25-42.

Shuler, C. (2009). Pockets of potential: Using mobile technologies to promote children's learning. New York: The Joan Ganz Cooney Center at Sesame Workshop.

Slykhuis, D. (2006). Have an iPod? Then you need to know this about how to use it in your classroom. In: C. Crawford et al. (Eds.) Proceedings of Society for Information Technology and Teacher Education International Conference 2006. Chesapeake, VA: AACE, 2416-2417.

Vardy, J., \& Kervin, L. (2007). Using iPod technology to engage primary students with the deconstruction and reconstruction of audio texts. Literacy Learning: the Middle Years, 15(1), 36-42.

Vardy, J., Kervin, L., \& Reid, D. (2007). iPods and podcasting technologies to support talking and listening experiences of grade 4 students. Literacy Learning: The Middle Years. 15(3), 57-70. 